\title{
Effects of halogenated metabolites from infaunal polychaetes on larval settlement of the spionid polychaete Streblospio benedicti
}

\author{
F. Esser, M. Winterberg, Z. Sebesvari, T. Harder* \\ Institute for Chemistry and Biology of the Marine Environment (ICBM), University of Oldenburg, 26129 Oldenburg, Germany
}

\begin{abstract}
Considering that a variety of infaunal polychaetes release halogenated metabolites with potent bactericidal effects into the surrounding sediment, we tested the hypothesis that polychaetederived halometabolites may either pose a direct negative effect on larvae or alter the bacterial community in surface sediments, and thus indirectly influence larval settlement. Commercially available halogenated compounds identical or similar to the dominant halometabolites found in Streblospio benedicti and Capitella sp. I served as experimental proxies in single- and multiple-choice settlement assays with larvae of $S$. benedicti. In multiple-choice assays, the hypothesis of a direct influence of halogenated proxies on larval settlement was verified with 1-chlorononane at concentrations of $3.5 \mathrm{\mu g} \mathrm{g}^{-1}$ sediment. A similar effect was not observed with 2,6-dibromophenol. The no-choice assays did not show a direct influence of halometabolites on polychaete larvae. On the other hand, the hypothesis of an indirect influence of halogenated proxies on larval settlement via modification of the sediment microbial assemblage was clearly rejected. However, an analysis of similarity of the PCR-amplified bacterial genes coding for 16S rRNA corresponding to distinct phylotypes revealed a significant change in bacterial community richness between untreated and natural sediment spiked and incubated with halogenated proxies for $7 \mathrm{~d}$. The change was characterized by the absence of up to 13 phylotypes and the appearance of up to 11 previously undetected phylotypes. The shift in bacterial community richness of sediments exposed to the halogenated proxies was not recognized by larvae, indicating that the halogenated proxies elicited no differential response in larvae of S. benedicti.
\end{abstract}

KEY WORDS: Halometabolites · Larval settlement - Polychaetes · Infauna · Bacteria $\cdot$ Sediment · Streblospio benedicti

Resale or republication not permitted without written consent of the publisher

\section{INTRODUCTION}

The occurrence of natural halogenated organic compounds among temperate marine infauna is widespread (Woodin et al. 1987, Fielman et al. 2001). A variety of infaunal polychaetes and hemichordates contain high concentrations of halogenated noxious secondary metabolites that are released into the sediment in the proximity of worm burrows (Ashworth \& Cormier 1967, Higa \& Scheuer 1975a,b, King 1986, Woodin et al. 1987, Steward et al. 1992, Lincoln et al. 2005).

In previous studies, the effect of halometabolites on microorganisms (Zsolnai 1960, Higa \& Scheuer 1975b,
Sheikh \& Djerassi 1975, King 1988, Reineke 2003), fish (Malins et al. 1987, Casillas \& Myers 1989) and fish eggs (Reineke 2003) was generally toxic. The potent deterrent effect of halometabolites on epibenthic predation by fishes and crabs at environmentally realistic sediment concentrations in the nano- to micromolar range indicated that these compounds may potentially play an ecological role in sediments populated by infaunal organisms (King 1986, 1988, Cowart et al. 2000, Reineke 2003). However, the role of halometabolites as biogenic antimicrobials thus far has not been unequivocally identified. For example, although bromophenols were assumed to selectively target micro- 
bial activity in worm burrows (King 1986, 1988), other studies did not detect any significant antimicrobial effect of this compound class (Jensen 1992, Steward et al. 1992, 1996, Steward \& Lovell 1997, Lovell et al. 1999). Besides their antimicrobial effect, biogenic haloaromatic metabolites have been demonstrated to reduce recruitment of heterospecific infauna and deter predators via allelopathy (Woodin et al. 1993, 1997, Cowart et al. 2000). The general hypothesis in all these studies was based on the assumption that the production of halometabolites serves as a defense strategy against microorganisms, predators and interspecific competition.

In addition to the direct role of biogenic halometabolites as negative settlement cues for infaunal polychaetes (Woodin et al. 1993, 1997), we tested the hypothesis that halometabolites may indirectly influence larval settlement of an infaunal polychaete Streblospio benedicti. The hypothesis was inspired by our previous finding that competent larvae of $S$. benedicti, albeit significantly rejecting ashed sediment in comparison with natural sediment, were stimulated to settle in ashed sediment that was re-inoculated with viable microorganisms obtained from natural sediment (Sebesvari et al. 2006). Thus, we raised the question whether polychaete-derived halometabolites may alter the microbial abundance and richness in surface sediments and, in turn, indirectly affect settlement of polychaete larvae.

We experimentally addressed this hypothesis with 2 infaunal polychaetes, Streblospio benedicti and Capitella sp. I. The adult organisms qualitatively differ in their halometabolite contents; $S$. benedicti contains at least 11 chlorinated and brominated alkylhalides (Fielman et al. 1999), whilst Capitella sp. I contains 3 brominated aromatic compounds (Cowart et al. 2000). For both species, the predominant halometabolites in worm tissues were determined and quantified by coupled gas chromatography-mass spectrometry (GC-MS). Commercially available halogenated compounds identical or similar to the dominant halometabolites in worm tissue served as experimental proxies in laboratory settlement assays with larvae of $S$. benedicti. In accordance with Cowart et al. (2000), $S$. benedicti mainly contained an unidentified isomer of chlorononane that was approximated with 1-chlorononane. Capitella sp. I mainly contained 2, 6-dibromophenol, which was commercially available.

To test the direct effect of halogenated proxies on larval settlement, sterilized sediment, i.e. without viable microorganisms, was mixed with individual halogenated compounds at different concentrations and subjected to larval settlement assays over time. The indirect effect was tested similarly, but with natural sediment, i.e. sediment containing viable microor- ganisms. These assays were accompanied by positive and negative controls of natural and sterile sediment, respectively. The concentration of added proxies was simultaneously measured when assays were evaluated for settlement rates of larvae. In a more ecologically realistic protocol adult Streblospio benedicti or Capitella sp. I were used to contaminate natural sediments with halometabolites and possibly modify the microbial community composition. To visualize and statistically compare the effect of halogenated proxies on the community composition of bacteria associated with the treated sediment and untreated controls, we applied the molecular fingerprinting tool of denaturing gradient gel electrophoresis (DGGE) of PCR-amplified 16S rRNA bacterial gene sequences. This approach was used to test whether the qualitative modification of the bacterial community associated with sediment due to exposure to halogenated metabolites resulted in less attractive sediment for larval settlement. The verification of this hypothesis would indicate a new ecological mechanism through which larval settlement of infaunal polychaetes is affected by adult polychaetes.

\section{MATERIALS AND METHODS}

Adult brood stocks and larval test organisms. Laboratory brood stocks of Streblospio benedicti were obtained at mud flats near Hooksiel, Germany $\left(53^{\circ} 38^{\prime} 31^{\prime \prime} \mathrm{N}, 8^{\circ} 04^{\prime} 55^{\prime \prime} \mathrm{E}\right)$. At the sampling site, $S$. benedicti occurs at densities of 5000 ind. $\mathrm{m}^{-2}$ (authors' pers. obs.). Adults and larvae were cultured under laboratory conditions according to Sebesvari et al. (2006). Every day newly hatched larvae were sieved (50 $\mu \mathrm{m}$ mesh) and rinsed into aerated culture vessels. The larval age distribution within the same batch differed by $24 \mathrm{~h}$ at maximum. Larvae reached competence after 6 to $8 \mathrm{~d}$. Larval competence was estimated according to larval body length and the number of setigers (Sebesvari et al. 2006). To ensure larval competence and selectivity, 2 no-choice settlement assays were performed. First, an aliquot of test larvae was subjected to a positive control known to trigger settlement, i.e. fresh natural sediment obtained from the natural habitat. Second, an aliquot of test larvae was subjected to a negative control rejected by larvae, i.e. ashed sediment. If larval settlement in the negative control was significantly lower than in the positive control, larvae were considered suitable for subsequent bioassays.

Laboratory brood stocks of Capitella sp. I were obtained from J. M. Rosario (Institute of Marine and Coastal Sciences, Rutgers State University, New Jersey, USA). Larvae were obtained and reared according to Grassle \& Grassle (1976) and Butman \& Grassle (1992). 
Sediment. Sediment was collected during low tide in mudflats of Hooksiel, Germany (53 38' $31^{\prime \prime} \mathrm{N}$, $8^{\circ} 04^{\prime} 55^{\prime \prime}$ E) throughout the summer of 2006. Newly collected sediment was stored in the dark in plastic containers at $4^{\circ} \mathrm{C}$ for no longer than $1 \mathrm{wk}$ (referred to as 'natural sediment'). Natural sediment was sterilized by autoclaving prior to bioassays (referred to as 'sterile sediment'). Natural sediment was combusted to ash at $600^{\circ} \mathrm{C}$ for $4 \mathrm{~h}$ in a muffle kiln. Before use in the bioassay, ashed sediment was covered with sterile filtered seawater and autoclaved (referred to as 'ashed sediment').

Larval settlement assays. Larval settlement assays with single- and multiple-choice options were performed in still water.

No-choice: Settlement assays with only a single choice of sediment for larvae were performed with different sediment treatments in sterile 12 well microplates (3.8 $\mathrm{cm}^{2}$ well surface area, Corning). A $2.5 \mathrm{~g}$ (wet weight) aliquot of sediment was transferred into each well, resulting in a layer of $7 \mathrm{~mm}$ sediment. The sediment was covered with $1.75 \mathrm{ml}$ of sterile-filtered seawater (i.e. filtered through $0.22 \mu \mathrm{m}$ membranes) and 10 larvae were added into each well. Experimental dishes were incubated for $1 \mathrm{~h}$ with replication $(\mathrm{n}=$ 12). Afterwards, swimming larvae were stained with the vital stain Neutral Red (Sigma) at $10 \mathrm{ng} \mathrm{ml}^{-1}$ for $1 \mathrm{~h}$. Stained larvae were counted under a stereomicroscope. Stained larvae without burrowing activity on the sediment surface were interpreted as not settled. Natural (positive control) and sterile or ashed sediment (negative control) were assayed at the same time. Assays were always performed with larvae obtained from the same batch.

Multiple-choice: Multiple-choice settlement assays were performed with 4 different sediment treatments in sterile, cylindrical, Plexiglas plates $(17 \times 1.5 \mathrm{~cm})$ containing 16 cylindrical holes $(2 \times 0.3 \mathrm{~cm})$ and equipped with a removable bottom. The wells were arranged in 4 rows and 4 columns separated by $1 \mathrm{~cm}$. In a $4 \times 4$ Latin-square design, 4 replicates of different sediment treatments were transferred into wells, i.e. every sample was placed exactly once per row and column. The plate was filled with $200 \mathrm{ml}$ of sterile-filtered seawater and ca. 1000 larvae were added. After 20 h, the water was poured off and the bottom was removed. Individual sediment samples were transferred onto glass plates. Settled larvae were stained as described previously and counted under the stereomicroscope. The settlement index in replicated samples was calculated based on the total number of settled larvae (100\%), discounting all larvae still swimming or lying on the sediment surface without burrowing activity.

Specimen collection and compound extraction. Adult worms were pooled from laboratory brood stocks. The average length and width $(\mathrm{n}=10)$ of adult specimens was measured under the binocular microscope and the tissue volume was calculated assuming a cylindrical shape of worms. The extraction consisted of placing pooled worms (60 individuals of Streblospio benedicti and 40 individuals of Capitella sp. I) in $600 \mu \mathrm{l}$ of GC-MS grade acetone ( $S$. benedicti) or methanol (Capitella sp. I). Samples were stored for $48 \mathrm{~h}$ at $4^{\circ} \mathrm{C}$. Insoluble tissue material was separated by centrifugation and the supernatant dried in vacuo. The dry extract residue was dissolved in $50 \mu \mathrm{l}$ of acetone or methanol for quantification.

Sample analysis. Samples were analyzed using coupled GC-MS. All samples were centrifuged prior to analysis to remove particular matter. A WCOT VF-5ms capillary column (Varian) $(30 \mathrm{~m} \times 0.25 \mathrm{~mm} \times 0.25 \mu \mathrm{m}$ film thickness) was used on a Varian 3900 gas chromatograph equipped with a Saturn 2100T (Varian) ion trap mass selective detector. Samples were injected in splitless mode with an inlet pressure of $72 \mathrm{kPa}$. The injection port and the interface were held at $270^{\circ} \mathrm{C}$. The gas chromatograph temperature was held at $70^{\circ} \mathrm{C}$ for $3 \mathrm{~min}$ and increased at $5^{\circ} \mathrm{C} \mathrm{min}^{-1}$ to $210^{\circ} \mathrm{C}$ (for Streblospio benedicti and spiked sediment) or $150^{\circ} \mathrm{C}$ (for Capitella sp. I and spiked sediment), then at $50^{\circ} \mathrm{C} \mathrm{min}^{-1}$ to $320^{\circ} \mathrm{C}$ and held for $3 \mathrm{~min}$. Helium was used as the carrier gas. The mass selective detector was operated in scan mode (specific mass to charge ratio, $\mathrm{m} / \mathrm{z}$, of 40 to 350 ). The electron impact ion-spectra of volatile tissue extract components were compared with entries in the National Institute of Standards and Technology (NIST) mass spectral library (NIST 05).

A calibration using halogenated proxies was performed with 1-chlorononane and 2,6-dibromophenol (Sigma Aldrich). The average concentrations of halogenated proxies were calculated from the mean of 3 injections of each sample. Following this protocol, we determined the resulting average amount of the sum of chlorononane isomers (for Streblospio benedicti) and dibromophenols (for Capitella sp. I) to be $70.57 \pm 0.08$ $\mathrm{ng} \mathrm{mm} \mathrm{m}^{-3}$ (mean $\pm \mathrm{SE}$ ) and $20.71 \pm 1.65 \mathrm{ng} \mathrm{mm}^{-3}$ tissue volume, respectively (Table 1 ).

Spiking of sediment with halogenated proxies. The amount of halogenated proxies used to spike sediment aliquots of $2.5 \mathrm{~g}$ each (see 'Bioassays') was equivalent to the concentration of chlorononane isomers and dibromophenols determined in 20 adults (referred to as $1 \times$ concentration). This final target concentration reflected a homogeneous distribution of halometabolites under the assumption that these compounds were completely dissolved in the sediment. Given the possibility that halometabolites were more patchily distributed in spots of high concentration (e.g. worm burrows), a 10-fold elevated target concentration of halogenated proxies was used in bioassays as well 
Table 1. Gas chromatography-mass spectrometry (GC-MS) analysis of tissue extracts of adult Streblospio benedicti and Capitella sp. I. Where possible, compounds and formulae were identified by comparison with the mass spectral database (NIST 05); otherwise, detected compounds are labelled as unidentified halogenated hydrocarbons $\left(\mathrm{C}_{n} \mathrm{H}_{n}\right)$. Characteristic ions list dominant mass fragments. The concentration of identified compounds is given in $\mathrm{ng} \mathrm{mm}^{-3}( \pm \mathrm{SD})$ for selected compounds. nd: not determined

\begin{tabular}{|lccrr|}
\hline Compounds & Characteristic ions & Formula & $\begin{array}{r}\text { Retention } \\
\text { time (min) }\end{array}$ & $\begin{array}{c}\text { Concentration } \\
\left(\mathrm{ng} \mathrm{mm}^{-3}\right)\end{array}$ \\
\hline Streblospio benedicti & & & & \\
Dichlorinated hydrocarbon & $91,93,119,121$ & $\mathrm{C}_{\mathrm{n}} \mathrm{H}_{\mathrm{n}} \mathrm{Cl}_{2}$ & $\mathrm{nd}$ \\
Brominated hydrocarbon & $135,137,149,151$ & $\mathrm{C}_{\mathrm{n}} \mathrm{H}_{\mathrm{n}} \mathrm{Br}$ & 10.75 & $\mathrm{nd}$ \\
Unidentified chlorononane isomer & $91,93,119,121,147,149$ & $\mathrm{C}_{9} \mathrm{H}_{19} \mathrm{Cl}$ & 11.36 & $19.59 \pm 7.7$ \\
Unidentified chlorononane isomer & $91,93,119,121,147,149$ & $\mathrm{C}_{9} \mathrm{H}_{19} \mathrm{Cl}$ & 14.22 & $50.98 \pm 8.6$ \\
Capitella sp. I & & & & \\
2,6-dibromophenol & $162,164,250,252,254$ & $\mathrm{C}_{6} \mathrm{H}_{4} \mathrm{Br}_{2} \mathrm{O}$ & 15.01 & $18.11 \pm 4.5$ \\
2,6-dibromo-4-methyl-phenol & $263,265,267,252$ & $\mathrm{C}_{7} \mathrm{H}_{6} \mathrm{Br}_{2} \mathrm{O}$ & 17.79 & $2.6 \pm 1.2$ \\
2,4-dibromo-6-(bromomethyl)phenol & $215,217,263,265,267$ & $\mathrm{C}_{7} \mathrm{H}_{5} \mathrm{Br}_{3} \mathrm{O}$ & 25.87 & $\mathrm{nd}$ \\
\hline
\end{tabular}

(referred to as 10× concentration). Stock solutions of the halogenated proxies 1-chlorononane and 2,6-dibromophenol were prepared in $100 \mu \mathrm{l}$ of acetone and methanol, respectively. Aliquots of the stock solutions were diluted with $5 \mathrm{ml}$ of sterile-filtered seawater and mixed with sterile or natural sediment. The final target concentrations in sediment treatments for bioassay purposes were 0.56 and $5.6 \mu \mathrm{g} 1$-chlorononane $\mathrm{g}^{-1}$ sediment, and 0.165 and $1.65 \mu \mathrm{g}$ 2,6-dibromophenol $\mathrm{g}^{-1}$ sediment. Blank controls were prepared by adding $100 \mu \mathrm{l}$ of methanol or acetone to sediment treatments.

To determine the actual concentration of halogenated proxies in spiked sediments, sediment aliquots were extracted. Briefly, $5 \mathrm{~g}$ of spiked sediment were centrifuged at $3900 \times g$ for $10 \mathrm{~min}$ to discard the pore water containing dissolved proxies. Sediments were extracted with $3 \mathrm{ml}$ of dichloromethane for $1 \mathrm{~h}$ on a rotor shaker. After centrifugation the supernatant was collected. The extraction was repeated and pooled supernatants were concentrated by rotary evaporation, followed by solid phase extraction on silica cartridges. The dichloromethane eluate was reduced to $100 \mu \mathrm{l}$ and used for quantification of halogenated proxies by GC-MS as described previously.

Bioassays. Direct effect of halogenated proxies on larval settlement: In a replicated no-choice assay $(\mathrm{n}=2)$ the halogenated proxies, 1-chlorononane and 2,6-dibromophenol, were assayed at both spiking concentrations along with natural sediment (positive control), ashed and autoclaved sediments (negative controls), and the solvent treatments (blank controls). In multiple-choice assays with replication $(n=3)$, each of the halogenated proxies at $1 \times$ and $10 \times$ concentrations were tested along with the negative control and the blank control. In another set of multiple-choice assays, the different halogenated proxies at $10 \times$ concentration were assayed along with the positive and negative controls.
Indirect effect of adult worms and halogenated proxies on larval settlement: Aliquots of $2.5 \mathrm{~g}$ (wet weight) natural sediment were populated with 20 adult worms of either species. In parallel, natural sediment was spiked with halogenated proxies at $10 \times$ concentration as described previously. The sediment treatments were transferred into multiple-choice test chambers along with natural sediment and incubated for $7 \mathrm{~d}$ in an aerated aquarium filled with natural seawater (32 ppt, $16^{\circ} \mathrm{C}$ ) under a $12 \mathrm{~h}$ dark:12 h light cycle. After $7 \mathrm{~d}$, test chambers were carefully retrieved and the seawater in the wells was removed. The remaining test wells were filled with sterile sediment and bioassays were carried out as described previously. Aliquots of $1 \mathrm{~g}$ of each sediment treatment were sampled to determine the concentration of halogenated proxies at the beginning and end of the experiment and for bacterial community analyses.

Bacterial community analysis in sediment treatments. To extract microbial community DNA associated with sediment, $1 \mathrm{~g}$ aliquots of sediment were sampled and mixed with $1 \mathrm{ml}$ of DNA extraction buffer (100 mM Tris-HCl [pH 8.0], 100 mM Na $\mathrm{Na}_{2}$-EDTA [pH 8.0], $100 \mathrm{mM}$ sodium phosphate [pH 8.0], $1.5 \mathrm{M}$ sodium chloride, $1 \%$ cetyltrimethylammonium bromide, $2 \%$ sodium dodecylsulfate [pH 7.5]) in sterile $2 \mathrm{ml}$ screw-cap vials and stored at $-20^{\circ} \mathrm{C}$. Samples were repeatedly frozen in liquid nitrogen and defrosted in warm water $\left(65^{\circ} \mathrm{C}\right)$. Bacterial cells were enzymatically lysed by addition of $20 \mu \mathrm{l}$ Proteinase K $\left(20 \mathrm{mg} \mathrm{ml}^{-1}\right.$ ) and incubation for $30 \mathrm{~min}$ at $37^{\circ} \mathrm{C}$ with gentle shaking. Subsequently, $100 \mu \mathrm{l}$ of sterile-filtered sodium dodecylsulfate $(20 \%)$ was added and the samples were incubated for $2 \mathrm{~h}$ at $65^{\circ} \mathrm{C}$. After centrifugation, the supernatants were mixed with an equal volume of chloroform-isoamyl alcohol (24:1, v/v) for $15 \mathrm{~min}$. The DNA in the aqueous phase was precipitated by the addition of 0.6 volumes of isopropanol and 
storage at $4{ }^{\circ} \mathrm{C}$ overnight. Crude DNA was pelleted by centrifugation, washed twice with cold $70 \%$ ethanol and dissolved in $50 \mu \mathrm{l}$ of sterile deionized water. Crude aliquots of community DNA were stored at $-20^{\circ} \mathrm{C}$ until use.

Amplification of 16S-rRNA genes in bacterial community DNA was performed by PCR in a total volume of $50 \mu \mathrm{l}$ containing $1 \mu \mathrm{l}$ of DNA template, $20.5 \mu \mathrm{l}$ sterile deionized water, $5 \mu \mathrm{l}$ PCR buffer, $2 \mathrm{mM}$ of each dNTP, $7.5 \mu \mathrm{l} 0.1 \%$ bovine serum albumin (BSA), $0.1 \mathrm{mM} \mathrm{MgCl}_{2}, 10 \mathrm{pM}$ of each universal primer: 341F (5'-ATT ACC GCG GCT GCT GG-'3) and 534R_GC (5'-CGC CCG CCG CGC GCG GCG GGC GGG GCG GGG GCA CGG GGG GCC TAC GGG AGG-3') (Muyzer et al. 1993), and 0.5 units of Taq polymerase (peqlab). After the initial denaturing cycle at $95^{\circ} \mathrm{C}$ for $3 \mathrm{~min}$, samples were amplified with 2 cycles at $94^{\circ} \mathrm{C}$ for $30 \mathrm{~s}, 64^{\circ} \mathrm{C}$ for $30 \mathrm{~s}$ and $72^{\circ} \mathrm{C}$ for $1 \mathrm{~min}$, followed by 9 touchdown cycles starting with $94^{\circ} \mathrm{C}$ for $30 \mathrm{~s}, 63^{\circ} \mathrm{C}$ minus $1^{\circ} \mathrm{C}$ per cycle for $30 \mathrm{~s}$ and $72^{\circ} \mathrm{C}$ for $1 \mathrm{~min}$, and 25 cycles of $94^{\circ} \mathrm{C}$ for $30 \mathrm{~s}, 54^{\circ} \mathrm{C}$ for $30 \mathrm{~s}$ and $72^{\circ} \mathrm{C}$ for $1 \mathrm{~min}$, followed by a final extension step at $72^{\circ} \mathrm{C}$ for $10 \mathrm{~min}$. A negative control containing the PCR master mix without template DNA was run in parallel. After the amplification, $4 \mu \mathrm{l}$ of each PCR amplicon was electrophoresed along with a $1000 \mathrm{bp}$ ladder, a positive control prepared from 7 bacterial isolates and the negative control on a $1.0 \%$ agarose gel in $1 \times$ TAE at $70 \mathrm{~V}$ for $30 \mathrm{~min}$. The resulting PCR product of $193 \mathrm{bp}$ was stained with ethidium bromide.

For DGGE, $30 \mu$ l of PCR product was loaded on a $6.5 \%(\mathrm{w} / \mathrm{v})$ polyacrylamide gel. An optimal separation was achieved with a gradient of 40 to $75 \%$ denaturant from top to bottom $(100 \%$ denaturant was defined as $7 \mathrm{M}$ urea and $40 \%$ (v/v) formamide. DGGE was performed with a PhorU-System (Ingeny) in $1 \times$ TAE running buffer at $60^{\circ} \mathrm{C}$ for $18 \mathrm{~h}$ at $100 \mathrm{~V}$. Gels were stained for $30 \mathrm{~min}$ in SybrGold nucleic acid stain (Molecular Probes) according to the manufacturer's protocol.

The gel banding patterns of different samples were subject to cluster analysis. Bray Curtis similarities were used to produce a similarity matrix based on the total number of bands found in all samples and the presence or absence of these bands in individual samples. For the construction of a dendrogram depicting the similarity of microbial communities in different samples, group average linkage and hierarchical agglomerative clustering was performed using the PRIMER v5 computer program (Plymouth Marine Laboratory).

Statistical analysis. In no-choice assays, larval settlement was expressed as percentage and tested for normal distribution (Shapiro-Wilks' $W$-test). Since per- centage settlement data were mostly not normally distributed, they were rank-transformed prior to further statistical analyses. After rank transformation, settlement data were analyzed by 1-way ANOVA followed by Tukey's multiple comparison test (Conover \& Iman 1980).

In multiple-choice assays, the number of counted larvae was $\log (x+1)$ transformed. Levene's test was employed to check the assumption of homogeneity. Where significant heterogeneity of variance could not be removed by transformation, a lower significance level ( $p=0.01$ instead of $p=0.05$ ) was used (Underwood 1997). Fixed factor effects of row, column and treatment on larval settlement were analyzed by maineffect ANOVA. If the treatment effect was significant, Tukey's multiple comparison test was used to identify differences among treatments.

\section{RESULTS}

\section{Identification and quantification of halometabolites in tissue extracts}

The chemical analysis of Streblospio benedicti tissue revealed 3 chlorinated and 1 brominated compound (Table 1). Two unknown isomers of chlorononane were identified according to characteristic diagnostic ions and mass spectroscopic fragmentation patterns and quantified with 1-chlorononane as a proxy. The amount (mean $\pm \mathrm{SE}$ ) of $70.57 \pm 0.08 \mathrm{ng}$ chlorononane $\mathrm{mm}^{-3}$ tissue volume was used to set the concentration of 1-chlorononane in the settlement assays. The amount of $20.71 \pm 1.65 \mathrm{ng}$ dibrominated phenolic compounds $\mathrm{mm}^{-3}$ tissue volume was used to set the concentration of the halogenated proxy 2,6-dibromophenol in the settlement assays.

\section{Quantification of halogenated proxies in spiked sediment treatments}

The recovery of halogenated proxies differed significantly by compound and by the residence time of compounds in sediments (Table 2). Although 50 to $60 \%$ of the 1 -chlorononane could be recovered immediately after the spiking procedure, the concentration was below the detection limit of $10 \mu \mathrm{g} \mathrm{ml}^{-1}$ after $7 \mathrm{~d}$ of incubation of similarly spiked natural and sterile sediment. The recovery of 2,6-dibromophenol was below $10 \%$ after immediate extraction and could not be detected in aged sediment treatments. The background concentration of 1-chlorononane and 2,6-dibromophenol in natural and sterilized sediment was below the detection limit. 
Table 2. Mean $( \pm \mathrm{SD})$ recovery concentrations of 1-chlorononane (CLN) and 2,6-dibromophenol (DBP) in natural (N) and sterile (S) sediment treatments spiked with 5.64 $\mu \mathrm{g}$ CLN and $1.65 \mu \mathrm{g}$ DBP $\mathrm{g}^{-1}$ sediment. Sediment treatments were analyzed by GC-MS at the beginning ( $0 \mathrm{~d}$ ) and after $7 \mathrm{~d}$ of incubation. Natural and sterile sediments without halometabolites served as controls. -: halometabolite concentrations were below the detection limit

\begin{tabular}{|c|c|c|c|}
\hline $\begin{array}{l}\text { Incubation } \\
\text { (d) }\end{array}$ & $\begin{array}{l}\text { Sediment } \\
\text { treatment }\end{array}$ & $\begin{array}{c}\text { Recovery } \\
(\%)\end{array}$ & $\begin{array}{c}\text { Concentration } \\
\left(\mu \mathrm{g} \mathrm{g}^{-1} \text { sediment }\right)\end{array}$ \\
\hline \multirow[t]{2}{*}{0} & $\mathrm{~N}-\mathrm{CLN}$ & $52.06 \pm 10.15$ & $2.94 \pm 0.70$ \\
\hline & $\mathrm{S}-\mathrm{CLN}$ & $62.04 \pm 10.64$ & $3.499 \pm 0.73$ \\
\hline \multirow[t]{2}{*}{7} & $\mathrm{~N}-\mathrm{CLN}$ & - & - \\
\hline & $\mathrm{S}-\mathrm{CLN}$ & - & - \\
\hline \multirow[t]{2}{*}{0} & $\mathrm{~N}-\mathrm{DBP}$ & $2.75 \pm 1.95$ & $0.045 \pm 0.023$ \\
\hline & $\mathrm{S}-\mathrm{DBP}$ & $11.93 \pm 7.71$ & $0.196 \pm 0.14$ \\
\hline \multirow[t]{2}{*}{7} & $\mathrm{~N}-\mathrm{DBP}$ & - & - \\
\hline & $\mathrm{S}-\mathrm{DBP}$ & - & - \\
\hline \multirow[t]{2}{*}{0} & $\mathrm{~N}$ - control & - & - \\
\hline & $\mathrm{S}$ - control & - & - \\
\hline \multirow[t]{2}{*}{7} & $\mathrm{~N}$ - control & - & - \\
\hline & S - control & - & - \\
\hline
\end{tabular}

Bioassays

Direct effect of halogenated proxies on larval settlement

In both experimental trials of the no-choice assay, no differences in percentage larval settlement were observed among sediment treatments spiked with both halogenated proxies regardless of the concentration used. These treatments evoked the same settlement response as the positive control of natural sediment. Only the negative control of ashed sediment significantly reduced larval settlement (1-way ANOVA: p < 0.05; Tukey's test: $\mathrm{p}<0.05)$. The organic solvent controls did not interfere with larval settlement (Fig. 1).

A different result of a direct influence of halogenated proxies on larval settlement was observed when spiked sediment treatments were investigated in multiplechoice assays. In 3 experimental trials, larvae significantly rejected the 1 -chlorononane treatment at $10 \times$ concentration compared with the $1 \times$ concentrated treatment, the solvent control and the negative control of sterile sediment (1-way ANOVA: p < 0.05; Tukey's test: $\mathrm{p}<$ 0.001 ; Fig. 2). A similar experiment testing the effect of 2,6-dibromophenol at $10 \times$ and $1 \times$ concentrations did not reveal any differences among spiked sediment treatments, solvent control and the negative of sterile sediment (ANOVA: $p=0.977$; Fig. 3). When both halogenated proxies were assayed at $10 \times$ concentration together with the positive control of natural sediment and a negative control of sterile sediment, larvae significantly preferred natural sediment in 3 experimental trials (1-way ANOVA: $\mathrm{p}<0.05$; Tukey's test: $\mathrm{p}<0.01$; Fig. 4).

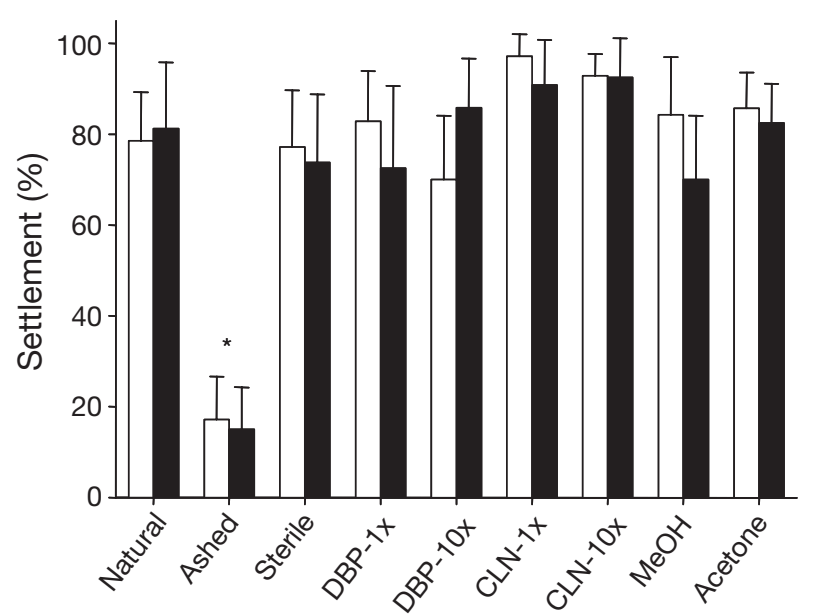

Fig. 1. Streblospio benedicti. Percentage of larval settlement in 2 experimental trials of single-choice assays (white and black bars) testing the direct effect of sterile sediments spiked with 2, 6-dibromophenol (DBP) and 1-chlorononane (CLN) at 1× and $10 \times$ concentrations. Controls were natural, sterile and ashed sediment and the solvent controls of acetone and methanol. ${ }^{*}$ Significant differences ( $\alpha=0.05$, Tukey's test). Data plotted are means $+\mathrm{SD}$

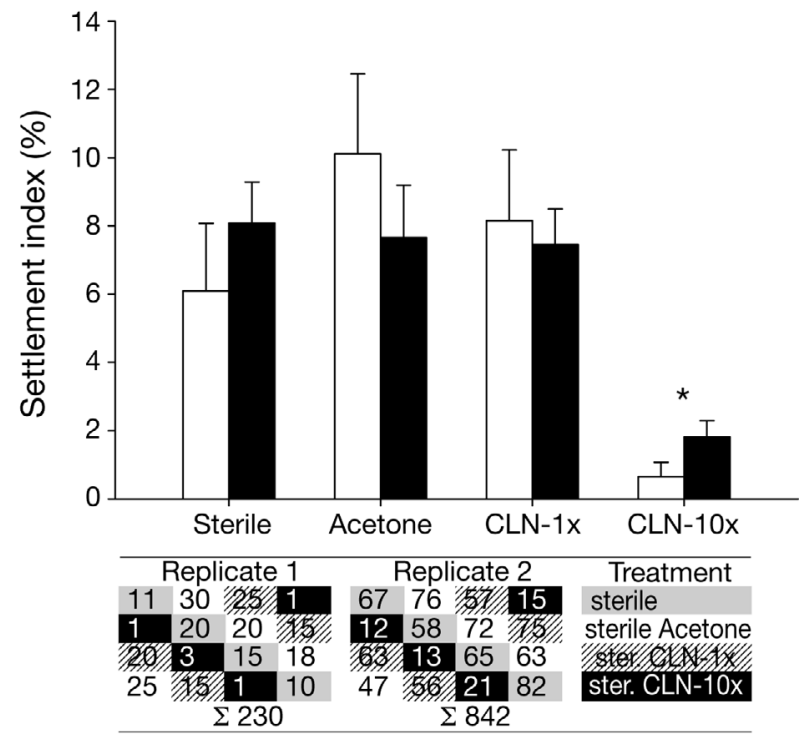

Fig. 2. Streblospio benedicti. Larval settlement index (\%) in 2 experimental trials (black and white bars) of multiple-choice assays testing the direct effect of sterile sediment spiked with 1 -chlorononane (CLN) at $1 \times$ and $10 \times$ concentrations together with a solvent control (acetone) and a negative control of sterile sediment. *Significant differences ( $\alpha=0.05$, Tukey's test). Data plotted are means $+\mathrm{SD}$. Table depicts the assay design and the total and individual number of settled larvae in individual wells 


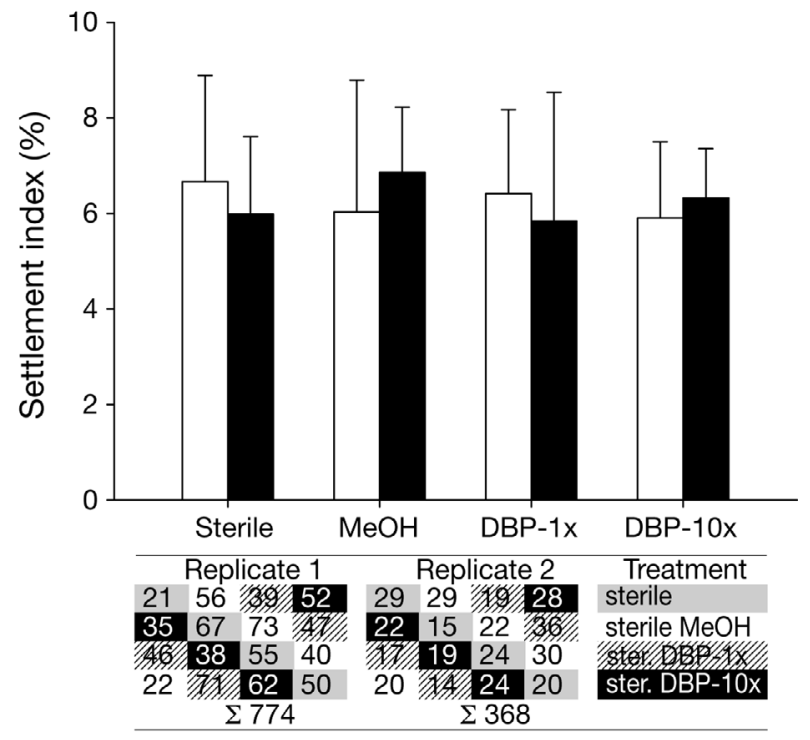

Fig. 3. Streblospio benedicti. Larval settlement index (\%) in 2 experimental trials (black and white bars) of multiple-choice assays testing the direct effect of sterile sediment spiked with 2,6-dibromophenol (DBP) at $1 \times$ and $10 \times$ concentrations together with a solvent control (methanol) and a negative control of sterile sediment. Data plotted are means + SD Table depicts the assay design and the total and individual number of settled larvae in individual wells

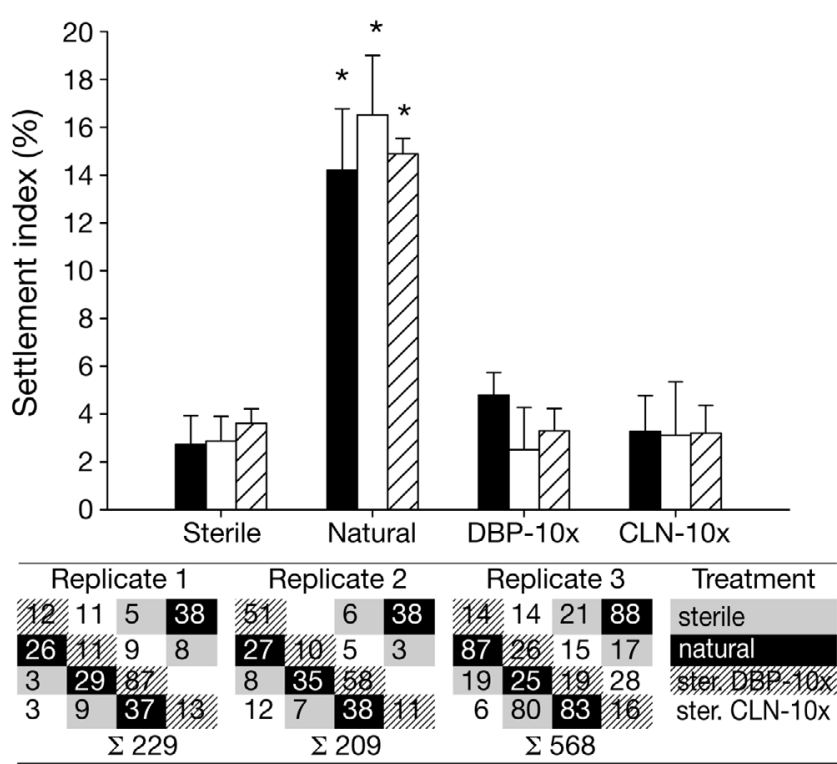

Fig. 4. Streblospio benedicti. Larval settlement index (\%) in 3 experimental trials (black, white, striped bars) of multiplechoice assays testing the direct effect of sterile sediment spiked with 2,6-dibromophenol (DBP) and 1-chlorononane (CLN) at $10 \times$ concentration together with a positive control of natural sediment and a negative control of sterile sediment. *Significant differences ( $\alpha=0.05$, Tukey's test). Data plotted are means + SD. Table depicts the assay design and the total and individual number of settled larvae in individual wells
Indirect effect of adult worms and halogenated proxies on larval settlement

In 3 experimental trials of the multiple-choice assay, larval settlement in natural sediment incubated for $7 \mathrm{~d}$ with halogenated proxies at $10 \times$ concentration was the same as in the positive control of natural sediment. Only the negative control of sterile sediment evoked a lower settlement index than the other treatments (1-way ANOVA: $p<0.05$; Tukey's test: $p<0.01$; Fig. 5). A similar result was obtained after natural sediment was populated with adult Streblospio benedicti and Capitella sp. I for $7 \mathrm{~d}$. In 3 experimental trials of the multiple-choice assay, larval settlement was the same in natural sediment and in adult-populated sediments. Only the negative control of sterile sediment evoked a lower settlement index than the other treatments (1-way ANOVA: $\mathrm{p}<0.001$; Tukey's test: $\mathrm{p}<0.001$; Fig. 6).

\section{Bacterial community analysis in natural, spiked and adult-populated sediments}

The 1 wk incubation experiments served to provide virgin and aged sediment samples $(n=3)$ of natural sediment, natural sediment spiked with halogenated

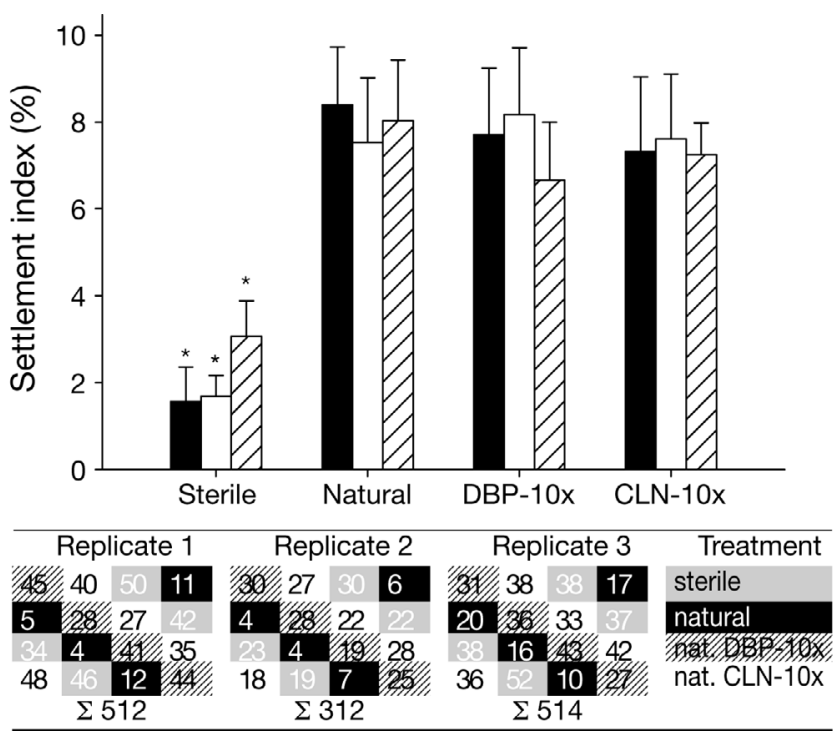

Fig. 5. Streblospio benedicti. Larval settlement index (\%) in 3 experimental trials (black, white, striped bars) of multiplechoice assays testing the indirect effect of natural sediment spiked with 2,6-dibromophenol (DBP) and 1-chlorononane (CLN) at $10 \times$ concentration and incubated in natural seawater for $7 \mathrm{~d}$ prior to the settlement assay. The positive control was virgin natural sediment and the negative control was sterile sediment. *Significant differences $(\alpha=0.05$, Tukey's test). Data plotted are means $+\mathrm{SD}$. Table depicts the assay design and the total and individual number of settled larvae in individual wells 


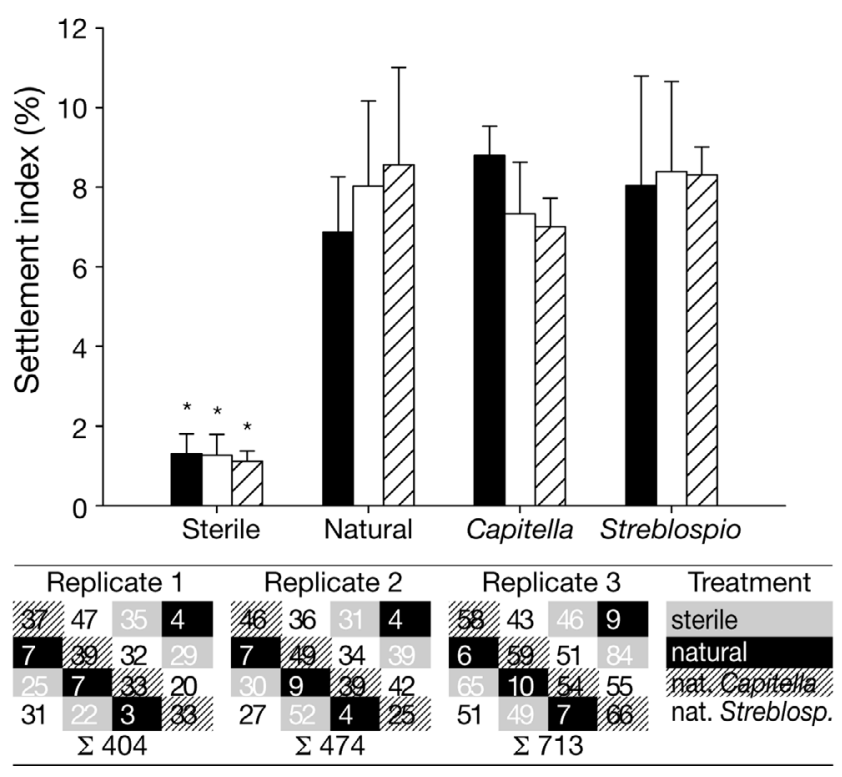

Fig. 6. Streblospio benedicti. Larval settlement index (\%) in 3 experimental trials (black, white, striped bars) of multiplechoice assays testing the indirect effect of natural sediment populated with live specimens of $S$. benedicti and Capitella sp. I, followed by $7 \mathrm{~d}$ of incubation in natural seawater. The positive control was virgin natural sediment and the negative control was sterile sediment. ${ }^{*}$ Significant differences $(\alpha=$ 0.05 , Tukey's test). Data plotted are means + SD. Table depicts the assay design and the total and individual number of settled larvae in individual wells

proxies, and adult-populated sediment. Two sediment samples populated with Streblospio benedicti were lost during the experiment. PCR amplicons obtained from all samples were developed on a single denaturing gradient gel. The bacterial communities obtained from spiked sediment treatments were characterized by the absence of bands in comparison with the control of natural sediment that presumably comprised a community of chemically unaffected bacteria. In adult-populated sediments additional bands were observed in comparison with the control of natural sediment, indicating a contamination of sediments with bacterial phylotypes originating from worms or a change in the bacterial community as a function of the worms' activities. These additional bands were omitted in the analysis of bacterial community patterns. With our combination of PCR primers, the number of discernible gel bands obtained from sediment treatments and controls ranged from 14 to 23. In total,
40 bands were used to create a similarity matrix based on Boolean character sets ( 1 or 0 ) corresponding to the presence or absence of a given band in a gel lane. The analysis of similarity (ANOSIM) of given bands per treatment produced a global R-value of $0.822(\alpha=$ 0.001). The pairwise comparisons of bacterial community richness in different sediment treatments resulted in no differences among all virgin sediment treatments at Day 0. Significant differences were observed between the same pairs of virgin and aged sediment treatments. Although the bacterial community richness in sediments populated with live adults for $7 \mathrm{~d}$ was the same, it differed in the corresponding sediment treatments spiked with species-specific halogenated proxies for $7 \mathrm{~d}$ (Table 3).

The cluster analysis of bacterial community richness associated with different sediment treatments and controls resulted in 4 subclusters (Fig. 7). The bacterial community richness associated with replicate sediment treatments revealed high similarities (data not shown).

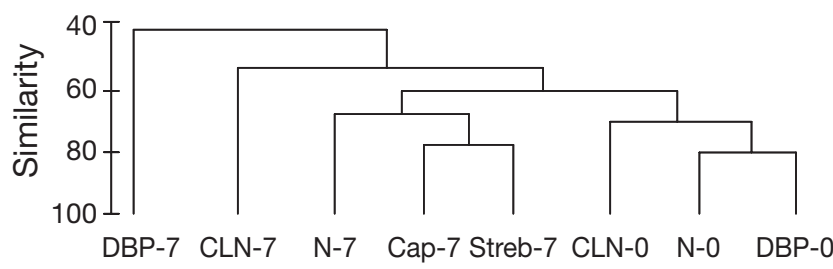

Fig. 7. Dendrogram showing the relatedness of sedimentassociated bacterial communities in virgin natural sediment at Days 0 and $7(\mathrm{~N}-0, \mathrm{~N}-7)$, natural sediment spiked with 1-chlorononane (10×) at Days 0 and 7 (CLN-0, CLN-7), natural sediment spiked with 2,6-dibromophenol (10×) at Days 0 and 7 (DBP-0, DBP-7) and natural sediment populated with adults $(\mathrm{n}=20)$ of Capitella sp. I and Streblospio benedicti for $7 \mathrm{~d}$ (Cap-7, Streb-7)

Table 3. Analysis of similarity (ANOSIM) of denaturing gradient gel electrophoresis (DGGE) patterns of bacterial community DNA $(n=3)$ in natural sediment at Days 0 and 7 (N-0, N-7), natural sediment spiked with 2,6-dibromophenol at Days 0 and 7 (DBP-0, DBP-7), natural sediment spiked with 1chlorononane at Days 0 and 7 (CLN-0, CLN-7) and natural sediment populated with adults of Capitella sp. I or Streblospipo benedicti after 7 d (Cap-7, Streb-7). Calculated R-values result from the analysis of present and absent gel bands for each treatment. The global R-value was $0.822 .{ }^{*}$ Statistical significance $(\alpha=0.05)$

\begin{tabular}{|lccccccc|}
\hline & N-0 & N-7 & DBP-0 & DBP-7 & CLN-0 & CLN-7 & Cap-7 \\
\hline N-7 & $0.833^{*}$ & - & & & & & \\
DBP-0 & 0.741 & $1.0^{*}$ & - & & & & \\
DBP-7 & $1.0^{*}$ & $1.0^{*}$ & $1.0^{*}$ & - & & & \\
CLN-0 & 0.426 & $0.889^{*}$ & 0.37 & $1.0^{*}$ & - & & \\
CLN-7 & $1.0^{*}$ & $1.0^{*}$ & $1.0^{*}$ & $1.0^{*}$ & $1.0^{*}$ & - & \\
Cap-7 & $1.0^{*}$ & $1.0^{*}$ & $1.0^{*}$ & $1.0^{*}$ & $1.0^{*}$ & $1.0^{*}$ & - \\
Streb-7 & $0.833^{*}$ & 0.611 & 0.556 & $0.889^{*}$ & $0.889^{*}$ & $0.889^{*}$ & 0.352 \\
\hline
\end{tabular}




\section{DISCUSSION}

Surface-associated microorganisms have been demonstrated to act as local signals and larval settlement cues in a wide variety of benthic invertebrate taxa settling on hard substrata (Pawlik 1992, Hadfield et al. 1994, Harder et al. 2002). Previously we studied whether a similar concept might also operate in infaunal organisms to guide burrowing behavior, metamorphosis and settlement. Using the spionid polychaete Streblospio benedicti, we demonstrated that competent larvae, albeit significantly rejecting experimental sediment lacking organic carbon, were stimulated to settle if this sediment was re-inoculated with viable microorganisms dissociated from natural sediment (Sebesvari et al. 2006). Considering that a variety of infaunal polychaetes produce and release halogenated metabolites into the surrounding sediment (Woodin et al. 1987, Steward et al. 1992, Fielman et al. 1999, Lincoln et al. 2005), we tested the hypothesis that polychaete-derived halometabolites may either have a direct negative effect on larvae or alter the bacterial richness in surface sediments of densely populated sediments, and, thus, indirectly influence larval settlement. Such an indirect interaction would represent a hitherto unrecognized role of biogenic halometabolites during settlement.

To investigate this hypothesis, we raised planktotrophic larvae of Streblospio benedicti in the laboratory and tested their settlement response in single- and multiple-choice assays of experimental sediments spiked with halogenated compounds. Halogenated compounds for spiking experiments were selected based on their occurrence and predominance in adult $S$. benedicti and Capitella sp. I. The total tissue concentrations of unidentified chlorononane isomers and dibrominated phenols in adult $S$. benedicti and Capitella sp. I obtained from our laboratory cultures was $70.57 \pm 0.08$ and $20.71 \pm 1.65 \mathrm{ng} \mathrm{mm}^{-3}$, respectively. These values fell into the same order of magnitude of total halogenated metabolites determined in adult $S$. benedicti obtained from intertidal mudflats in South Carolina, USA, and laboratory cultures of Capitella sp. I (Cowart et al. 2000). For the setup of experimental sediments the content of dominant, partially unidentified halometabolites was mimicked with commercially available compounds, using 1-chlorononane as a proxy for chlorononane isomers and 2,6-dibromophenol as a proxy for dibrominated phenols.

For our bioassays the concentrations of halogenated proxies in spiked experimental sediment aliquots of $2.5 \mathrm{~g}$ and $2 \mathrm{~cm}^{2}$ surface area were adjusted to be equivalent to the total concentration of halometabolites present in 20 adult worms. This calculation overestimated the actual population density of both spe- cies at the sampling site (ca. 5000 ind. $\mathrm{m}^{-2}$ ) roughly 20 -fold. However, the resulting sediment concentration of $0.165 \mu \mathrm{g}$ 2,6-dibromophenol $\mathrm{g}^{-1}$ was well within the range reported for a relatively large bromophenol-producing polychaete, Notomastus lobatus (Steward et al. 1992, Lovell et al. 1999). To the best of our knowledge, comparable quantifications of biogenic chlorinated hydrocarbons in surface sediments do not exist in the literature. Given the small size of our study organisms, we did not determine the concentrations of halometabolites in burrow linings and in close proximity. We purposely mimicked a homogenous distribution of the supposedly high concentration of halometabolites present in direct proximity to worm burrows in the entire experimental sediment to test the effect of halometabolites on sediment-associated bacteria in the topmost sediment layer. The rationale for this approach was based on our previous observations that competent polychaete larvae repeatedly touched the sediment surface with their ventral body parts prior to burrowing and settlement (Sebesvari et al. 2006).

To verify to what extent spiked halogenated proxies were bound to particulate organic matter in sediments and, thus, bioavailable to bacterial biofilms in the sediment, halogenated proxies in sediments were extracted and quantified. The recovery yields were surprisingly low and differed significantly between the 2 compounds, indicating that either the extraction efficiency was low, as previously demonstrated by Steward et al. (1992), and/or that a large proportion of spiked proxies did not adsorb to the sediment. To compensate for potential losses, the spiking concentration of halogenated proxies in multiple-choice assays was elevated 10 -fold, resulting in final recovery yields of ca. $3 \mu \mathrm{g}$ 1-chlorononane $\mathrm{g}^{-1}$ and 0.05 to $0.2 \mu \mathrm{g}$ 2,6-dibromophenol g ${ }^{-1}$ (Table 2). Given these concentrations of halogenated proxies in experimental sediment treatments, the hypotheses raised in this study were answered as follows.

Our first hypothesis of a direct influence of halogenated proxies on larval settlement of Streblospio benedicti strongly depended on the assay design. In the no-choice assay, settlement in sediment spiked with halogenated proxies was the same as in controls of natural and sterile sediment (Fig. 1). However, when larvae were given a choice between experimental treatments spiked with 1-chlorononane at different concentrations, there was a clear direct inhibitory effect of the high spiking concentration on larval settlement (Fig. 2). A similar effect was not observed with the other halogenated proxy 2,6-dibromophenol (Fig. 3). When larvae were offered both proxies at high concentrations together with the positive control alternative of untreated natural sediment, the spiked treat- 
ments were significantly rejected (Fig. 4). Given that larvae inspect the sediment surface repeatedly on small spatial scales of several $\mathrm{cm}^{2}$ (Sebesvari et al. 2006, authors' pers. obs.), these results indicate a potential direct effect of halometabolites on larval settlement, provided that surface properties differ within the investigated sediment patch. Thus, larval preferences observed in the field may partially result from a patchy distribution of halometabolites, even though the potential effect of hydrodynamics on larval settlement and substrate selection was not part of the present study. Flume studies that mimicked the effect of hydrodynamics revealed that larvae of Capitella sp. I were able to select substrates under conditions of water turbulence (Butman et al. 1988). The no-choice assay seemed inappropriate to resolve these preferences because larvae may loose their selectivity and comply with a moderately acceptable sediment quality after repeated exposure to the same negative stimulus.

Our second hypothesis of an indirect influence of halogenated proxies on larval settlement was clearly rejected. In 3 experimental trials of a multiple-choice assay testing the effect of $7 \mathrm{~d}$ incubations of natural sediments spiked with halogenated proxies, larval settlement was the same as in the positive control of natural sediment (Fig. 5). A direct effect of halogenated proxies on larval settlement as outlined previously could be ruled out, since the recovery of these compounds was below the detection limit after $7 \mathrm{~d}$ of incubation (Table 2). When live adult worms were incubated in natural sediment for the same duration, allowing the sediment to be contaminated with biogenic halometabolites, there was no difference in larval settlement between sediments populated with live worms and the unpopulated positive control of natural sediment (Fig. 6). These results suggested that (1) the overall inductive effect of viable bacteria on larval settlement as observed in the control treatments of natural sediment was unchanged in the presence or after the utilization of halometabolites, and (2) that potential changes in bacterial abundance and/or community richness as a consequence of long-term exposure to halometabolites or microbial utilization did not change the suitability of these sediments for settling larvae.

To evaluate the potential changes in bacterial community richness between virgin and the corresponding aged sediment treatments, the banding patterns obtained by DGGE were subject to similarity analysis. Since DGGE of PCR amplicons does not provide quantitative information of the bacterial community, the similarity analysis was based on the presence and absence of bacterial phylotypes (Muyzer et al. 1993, Murray et al. 1996, Rochelle 2001). To profile a bacterial constituent within a complex population by DGGE analysis of PCR-amplified genes coding for 16S rRNA, the minimum abundance must exceed $1 \%$ of the total population (Muyzer et al. 1993). The ANOSIM revealed a significant change in bacterial community richness between virgin and the corresponding aged sediment treatments. The PCR amplicons of DNA extracted from virgin natural sediment revealed 21 bands on the denaturing gradient gel. When natural sediment was incubated for $7 \mathrm{~d}$ in natural seawater prior to DNA extraction (i.e. aged natural sediment), 4 bands were no longer detected. The missing bacterial phylotypes may have been eliminated or reduced in abundance due to the lack of nutrients or bacterial dynamics in complex microbial assemblages (Costerton et al. 1995). Two of the phylotypes that were not detected in aged natural sediment were also absent in aged sediment treatments spiked with halogenated proxies. In contrast to the natural aged sediment, 4 additional bands were below the detection limit in aged sediment spiked with halogenated proxies. The missing bands had the same retention characteristic, indicating that they belonged to the same bacterial phylum, and were similarly affected by either one of the halogenated proxies. Aged sediment spiked with 2,6-dibromophenol revealed 9 other bacterial phylotypes below the detection limit compared with aged sediment spiked with 1-chlorononane. These results indicated that 2,6-dibromophenol markedly decreased the bacterial community richness present in natural sediment, supporting the earlier notion of strong bactericidal effects of bromometabolites (King 1986). Interestingly, in comparison with natural sediment, 11 and 4 additional phylotypes were observed in aged sediment spiked with 1-chlorononane and 2,6-dibromophenol, respectively. Although these bacterial types were presumably present in natural sediment, their absence may be explained with their low abundance in untreated sediment. It is possible that the additional phylotypes observed in sediment incubations treated with halogenated proxies increased in abundance due to the use of these compounds or metabolic byproducts of other bacteria within the population capable to remediate halogenated compounds. Contrary to these findings, there was no bactericidal effect of halometabolites released by live worms in the adult-populated sediments. The bacterial community richness in these samples was the same as in the aged treatment of natural sediment.

Studies employing intact sediment cores (Steward et al. 1992, Steward \& Lovell 1997, Lovell et al. 1999) or examining burrow linings that were not homogenized or incubated with a halogenated substrate (Alongi 1985, Jensen et al. 1992, Steward et al. 1996) have shown no inhibition of sediment microbiota by infaunal brominated metabolites. The accumulation of biogenic bromophenols in worm beds has been suggested 
to be limited by bacterial remediation (Steward \& Lovell 1997). Our study complies with the latter suggestion since recovery yields of halogenated compounds after short incubation times were low or no longer detectable. However, this study clearly demonstrates that halogenated compounds can reduce the bacterial community richness in sediment slurries and may be used by sediment-associated bacteria. Moreover, our results suggest that biogenic bromophenols have a significantly more pronounced limiting effect than chlorinated hydrocarbons on the bacterial community composition. The inhibition of sediment microflora in proximity to worm burrows and linings has been suggested to restrict the availability of microbially derived sources for carbon and nitrogen for worms (Newell 1965, Cammen 1980), alter sediment texture by reduced production of exopolymers and, thus, change sediment biogeochemical processes (Decho 2000). However, in the present study the potentially modified sediment quality as a result of a shift in bacterial community richness was not recognized by larvae of the polychaete Streblospio benedicti, indicating that biogenic halometabolites did not serve as indirect larval settlement cues in this species.

Acknowledgements. This study was supported by a grant from the German Research Foundation (DFG) to T.H. (HA 3496/2-2).

\section{LITERATURE CITED}

Alongi DM (1985) Microbes, meiofauna, and bacterial productivity in tubes constructed by the polychaete Capitella capitata. Mar Ecol Prog Ser 23:207-208

Ashworth RB, Cormier MJ (1967) Isolation of 2,6-dibromophenol from marine hemichordate Balanoglossus biminiensis. Science 155:1558-1600

Butman CA, Grassle JP (1992) Active habitat selection by Capitella sp. I. larvae. 1. 2-choice experiments in still water and flume flows. J Mar Res 50:669-715

Butman CA, Grassle JP, Webb CM (1988) Substrate choices made by marine larvae in still water and in a flume flow. Nature 333:771-773

Cammen LM (1980) The significance of microbial carbon in the nutrition of the deposit feeding polychaete Nereis succinae. Mar Biol 61:9-20

Casillas E, Myers MS (1989) Effect of bromobenzene and O-bromophenol on kidney and liver of English sole (Parophrys vetulus). Comp Biochem Physiol Part C Toxicol Pharmacol 93:43-48

Conover WJ, Iman RL (1980) The rank transformation as a method of discrimination with some examples. Commun Stat A-Theor 9:465-487

Costerton JW, Lewandowski Z, Caldwell DE, Korber DR, Lappin-Scott HM (1995) Microbial biofilms. Annu Rev Microbiol 49:711-745

Cowart JD, Fielman KT, Woodin SA, Lincoln DE (2000) Halogenated metabolites in two marine polychaetes and their planktotrophic and lecithotrophic larvae. Mar Biol 136: 993-1002
Decho AW (2000) Microbial biofilms in intertidal systems: an overview. Cont Shelf Res 20:1257-1273

Fielman KT, Woodin SA, Walla MD, Lincoln DE (1999) Widespread occurrence of natural halogenated organics among temperate marine infauna. Mar Ecol Prog Ser 181:1-12

Fielman KT, Woodin SA, Lincoln DE (2001) Polychaete indicator species as a source of natural halogenated organic compounds in marine sediments. Environ Toxicol Chem 20:738-747

Grassle JP, Grassle JF (1976) Sibling species in marine pollution indicator Capitella (Polychaeta). Science 192:567-569

Hadfield MG, Unabia CC, Smith CC, Michael TM (1994) Settlement preferences of ubiquitous fouler Hydroides elegans. In: Thompson MF, Nagabhushanam R, Sarojini R, Fingerman $M$ (eds) Recent developments in biofouling control. Oxford \& IBH, New Delhi, p 65-74

Harder T, Lam C, Qian PY (2002) Induction of larval settlement in the polychaete Hydroides elegans by marine biofilms: an investigation of monospecific diatom films as settlement cues. Mar Ecol Prog Ser 229:105-112

Higa T, Scheuer PJ (1975a) 3-chloroindole, principal odorous constituent of hemichordate Ptychodera flava laysanica. Naturwissenschaften 62:395-396

Higa T, Scheuer PJ (1975b) Constituents of marine annelid Thelepus setosus. Tetrahedron 31:2379-2381

Jensen P, Emrich R, Weber K (1992) Brominated metabolites and reduced numbers of meiofauna organisms in the burrow wall lining of the deep-sea enteropneust Streobalanus canadensis. Deep-Sea Res 39:1247-1253

King GM (1986) Inhibition of microbial activity in marine sediments by a bromophenol from a hemichordate. Nature 323:257-259

King GM (1988) Dehalogenation in marine sediments containing natural sources of halophenols. Appl Environ Microbiol 54:3079-3085

Lincoln DE, Fielmann KT, Marinelli RL, Woodin SA (2005) Bromophenol accumulation and sediment contamination by the marine annelids Notomastus lobatus and Thelepus crispus. Biochem Syst Ecol 33:559-570

Lovell CR, Steward CC, Phillips T (1999) Activity of marine sediment bacterial communities exposed to 4-bromophenol, a polychaete secondary metabolite. Mar Ecol Prog Ser 179:241-246

Malins DC, McCain BB, Myers MS, Brown DW and others (1987) Field and laboratory studies of the etiology of liver neoplasms in marine fish from Puget Sound. Environ Health Perspect 71:5-16

Murray AE, Hollibaugh JT, Orrego C (1996) Phylogenetic compositions of bacterioplankton from two California estuaries compared by denaturing gradient gel electrophoresis of 16S rDNA fragments. Appl Environ Microbiol 62:2676-2680

Muyzer G, de Wall EC, Uitterlinden AG (1993) Profiling of complex microbial population by denaturing gradient gel electrophoresis analysis of polymerase chain reaction amplified genes coding for 16S rRNA. Appl Environ Microbiol 59:695-700

Newell RC (1965) The role of detritus in the nutrition of two marine deposit feeders, the prosobranch Hydrobia ulvae and the bivalvae Macoma balthica. Proc Zool Soc Lond 144:25-45

Pawlik JR (1992) Chemical ecology of the settlement of benthic marine invertebrates. Oceanogr Mar Biol Annu Rev 30:273-335

Reineke N (2003) Biotestgeleitete Analytik von ökologisch relevanten organischen Substanzen in Sedimentextrakten von Nord- und Ostsee. PhD dissertation, University 
Hamburg

Rochelle P (2001) Environmental molecular microbiology: protocols and applications. Horizon Scientific Press, Wymondham

Sebesvari Z, Esser F, Harder T (2006) Sediment-associated cues for larval settlement of the infaunal spionid polychaetes Polydora cornuta and Streblospio benedicti. J Exp Mar Biol Ecol 337:109-120

Sheikh YM, Djerassi C (1975) 2,6-dibromophenol and 2,4,6-tribromophenols - antiseptic secondary metabolites of Phoronopsis viridis. Experientia 31:265-266

Steward CC, Lovell CR (1997) Respiration and assimilation of 4-bromophenol by estuarine sediment bacteria. Microb Ecol 33:198-205

Steward CC, Pinckney J, Piceno Y, Lovell CR (1992) Bacterial numbers and activity, microalgal biomass and productivity, and meiofaunal distribution in sediments naturally contaminated with biogenic bromophenols. Mar Ecol Prog Ser 90:61-71

Editorial responsibility: Joseph Pawlik, Wilmington, North Carolina, USA
Steward CC, Nold SC, Ringelberg DB, White DC, Lovell CR (1996) Microbial biomass and community structures in the burrows of bromophenol producing and non-producing marine worms and surrounding sediments. Mar Ecol Prog Ser 133:149-165

Underwood AJ (1997) Experiments in ecology: their logical design and interpretation using analysis of variance. University Press, Cambridge

Woodin SA, Walla MD, Lincoln DE (1987) Occurrence of brominated compounds in soft-bottom benthic organisms. J Exp Mar Biol Ecol 107:209-217

Woodin SA, Marinelli RL, Lincoln DE (1993) Allelochemical inhibition of recruitment in a sedimentary assemblage. J Chem Ecol 19:517-530

Woodin SA, Lindsay SM, Lincoln DE (1997) Biogenic bromophenols as negative recruitment cues. Mar Ecol Prog Ser 157:303-306

Zsolnai T (1960) Versuche zur Entdeckung neuer Fungistatika-I phenol-derivate. Biochem Pharmacol 5:1-19

Submitted: May 24, 2007; Accepted: August 28, 2007

Proofs received from author(s): February 1, 2008 